\title{
Distinct glucose-dependent stress responses revealed by translational profiling in pancreatic $\beta$-cells
}

\author{
Isabel C Greenman*, Edith Gomez*, Claire E J Moore and Terence P Herbert \\ Department of Cell Physiology and Pharmacology, University of Leicester, Maurice Shock Medical Sciences Building, University Road, Leicester LE1 9HN, UK \\ (Requests for offprints should be addressed to T P Herbert; Email: tph4@le.ac.uk) \\ *(I C Greenman and E Gomez contributed equally to this work)
}

\begin{abstract}
In pancreatic $\beta$-cells, following an acute (within $1 \mathrm{~h}$ ) increase in glucose concentration, there are rapid changes in the expression of a large subset of proteins. The change in the expression of many of these proteins is mediated by a post-transcriptional mechanism through either increases or decreases in the rate of translation from pre-existing transcripts. These proteins, whose synthesis is rapidly up- or down-regulated in response to glucose, are likely important in mounting the correct response to changes in plasma glucose concentrations. However, the vast majority of these proteins remain unidentified. Therefore, in order to identify these proteins, we analysed changes in the levels of mRNAs associated with polysomes (i.e. actively translating mRNAs) isolated from mouse insulinoma 6 cells incubated at either 0.5 or $20 \mathrm{mM}$ glucose for $1 \mathrm{~h}$. Changes in the levels of polysomal mRNAs in response to glucose were analysed using affymetrix oligonucleotide microarrays (translational profiling). This work revealed that, in response to a change in glucose concentration, the abundance of 313 transcripts associated with
\end{abstract}

polysomes changed by more than 1.5 -fold, of which the abundance of 37 changed by more than twofold. The majority of these transcripts encoded proteins associated with metabolism or gene expression. More detailed analysis showed that a number of mRNAs encoding proteins associated with the induction of oxidative stress, including thioredoxin-2 and thioredoxininteracting protein were rapidly redistributed onto heavier polysomes at high glucose concentration, indicating an increase in their expression. At low glucose concentration, when the general rate of protein synthesis is low, a number of mRNAs encoding integrated stress response proteins, including ATF4 and $\mathrm{CHOP} 10$, associate with heavier polysomes, indicating that their expression is up-regulated. In conclusion, translational profiling has revealed that, at either low or at high glucose concentration, $\beta$-cells rapidly increase the synthesis of a specific subset of proteins that are likely important in maintaining $\beta$-cell integrity and survival during conditions of nutritional stress.

Journal of Endocrinology (2007) 192, 179-187

\section{Introduction}

The pancreatic $\beta$-cell rapidly releases insulin in response to nutrients, such as amino acids or glucose (Campbell et al. 1982). To ensure the immediate replenishment of insulin within the $\beta$-cell, there is a rapid increase in proinsulin synthesis (up to 10 to 20 -fold within $40 \mathrm{~min}$ in response to glucose), which is regulated almost entirely through a posttranscriptional mechanism (Itoh et al. 1978, Itoh \& Okamoto 1980). Additionally, there are rapid changes in the synthesis of a large number of other proteins, also mediated through a post-transcriptional mechanism (Itoh \& Okamoto 1980, Guest et al. 1989, 1991). The vast majority of these proteins that are rapidly up- or down-regulated in response to glucose remain to be identified, but they are likely to be important in mounting the correct response to changes in plasma glucose concentrations. For example, the biogenesis of the secretory granule requires the co-ordinate synthesis and assembly of a large number of proteins (Guest et al. 1989, 1991). Moreover, inhibiting protein synthesis in islets by the addition of cycloheximide perturbs insulin secretion in response to glucose (Garcia-Barrado et al. 2001). Therefore, alterations in the normal synthesis of these proteins may result in defective storage or secretion of pro/insulin and symptoms associated with type II diabetes.

Although gene expression profiling of $\beta$-cells incubated at low versus high glucose concentrations has identified proteins that are transcriptionally regulated by glucose (Webb et al. 2000, 2001, Shalev et al. 2002, Ohsugi et al. 2004), increases in protein expression mediated solely through an increase in the rate of protein synthesis would not have been detected. Therefore, in order to identify proteins regulated by glucose through changes in their rate of protein synthesis, translational profiling of mouse insulinoma 6 (MIN6) cells acutely incubated at either low or high glucose concentration was performed (i.e. microarray analysis was performed on mRNAs associated with polysomes, as an increase in the association of mRNA with polysomes is indicative of an increase in the rate of initiation step of translation and hence an increase in protein expression (Johannes et al. 1999, Mikulits et al. 2000)). 


\section{Materials and Methods}

\section{Chemicals and materials}

Analytical grade biochemicals were purchased from Fisher Scientific or Sigma, unless otherwise specified. Klenow fragment and dNTPs were obtained from Promega. Hybond-N membrane, $\left[\alpha_{-}{ }^{32} \mathrm{P}\right]$ dCTP redivue tips, RNA guard and probequant G50 columns were obtained from Amersham Biosciences. Foetal calf serum was from Invitrogen.

\section{Cell culture and treatment}

MIN6 cells (kindly provided by Prof. Jun-Ichi Miyazaki) were used at approximately $80 \%$ confluence between passages 16 and 28. MIN6 cells were grown in Dulbecco's modified Eagle's medium containing $25 \mathrm{mM}$ glucose supplemented with $15 \%$ heat-inactivated foetal calf serum, $100 \mu \mathrm{g} / \mathrm{ml}$ streptomycin, 100 units $/ \mathrm{ml}$ penicillin sulphate and $75 \mu \mathrm{M}$ $\beta$-mercaptoethanol, equilibrated with $5 \% \mathrm{CO}_{2}, 95 \%$ air at $37{ }^{\circ} \mathrm{C}$. Prior to treatment, the medium was removed and the cells washed twice in HEPES-balanced Kreb's Ringer bicarbonate buffer $(115 \mathrm{mM} \mathrm{NaCl}, 5 \mathrm{mM} \mathrm{KCl}, 10 \mathrm{mM}$ $\mathrm{NaHCO}_{3}, 2.5 \mathrm{mM} \mathrm{MgCl} 2,2.5 \mathrm{mM} \mathrm{CaCl}$ and $20 \mathrm{mM}$ HEPES pH 7.4) containing $0 \cdot 5 \%$ BSA (KRB). Cells were then pre-incubated for $1 \mathrm{~h}$ at $37^{\circ} \mathrm{C}$ in $\mathrm{KRB}$ containing $0.5 \mathrm{mM}$ glucose (unless otherwise stated in the figure legends) prior to incubation in KRB containing 0.5 or $20 \mathrm{mM}$ glucose for a further hour (unless otherwise stated in the figure legends). During the final $10 \mathrm{~min}$ of treatment, cycloheximide was added to the cells at a concentration of $100 \mu \mathrm{g} / \mathrm{ml}$ to prevent ribosomal run-off.

\section{Insulin ELISA}

Insulin secretion assays were performed using the Insulin Mouse ELISA kit (DRG Instruments GmbH, Germany) in accordance with the manufacturer's instructions.

\section{Polysome analysis}

After treatment, cells were lysed in polysome buffer $(20 \mathrm{mM}$ HEPES $\mathrm{pH} 7 \cdot 6,15 \mathrm{mM} \mathrm{MgCl}_{2}, 300 \mathrm{mM} \mathrm{KCl}, 1 \mathrm{mg} / \mathrm{ml}$ heparin, $0 \cdot 1 \mathrm{mg} / \mathrm{ml}$ cycloheximide, $1 \mathrm{mM}$ dithiothreitol, $1 \mu \mathrm{l} / \mathrm{ml}$ RNAguard, $1 \mathrm{mM}$ benzamidine- $\mathrm{HCl}, 0 \cdot 1 \mathrm{mM}$ phenylmethylsulfonyl fluoride, $1 \mu \mathrm{g} / \mathrm{ml}$ leupeptin and $1 \mu \mathrm{g} / \mathrm{ml}$ pepstatin) supplemented with $1 \%$ triton. Cell lysates were centrifuged for $10 \mathrm{~min}$ at $13000 \mathrm{~g}$ at $4{ }^{\circ} \mathrm{C}$ to remove nuclei and cell debris. The supernatants were then layered onto $20-50 \%$ sucrose gradients (made in polysome buffer) and centrifuged at 39000 r.p.m. for $2 \mathrm{~h}$ at $4{ }^{\circ} \mathrm{C}$ in a Sorvall TH64.1 rotor. The gradients were fractionated using a Teledyne ISCO, NE, USA gradient fractionator that continuously measured absorbance at $254 \mathrm{~nm}$. For northern-blot analysis, RNA was precipitated overnight at $-80{ }^{\circ} \mathrm{C}$ from each fraction by the addition of three volumes of $8 \mathrm{M}$ guanidine- $\mathrm{HCl}$ and four volumes of ethanol. RNA was pelleted by centrifugation, washed in $75 \%$ ethanol, dried and resuspended in $\mathrm{H}_{2} \mathrm{O}$. For microarray analysis, fractions containing polysomes (more than three ribosomes) were pooled. Three volumes of $8 \mathrm{M}$ guanidine- $\mathrm{HCl}$ and $0.1 \mathrm{M}$ sodium acetate was added to 1 volume of the pooled RNA. An equal volume of ethanol was added and RNA was precipitated at $-80{ }^{\circ} \mathrm{C}$ overnight. RNA was pelleted by centrifugation at $12000 \mathrm{~g}$ for $15 \mathrm{~min}$, washed in $75 \%$ ethanol and dried. RNA pellets were then resuspended in $\mathrm{H}_{2} \mathrm{O}$ and an equal volume of $5 \mathrm{M} \mathrm{LiCl}$ was added. RNA was precipitated overnight at $-80{ }^{\circ} \mathrm{C}$ and then pelleted by centrifugation at $12000 \mathrm{~g}$ for $15 \mathrm{~min}$. RNA pellets were then washed in $75 \%$ ethanol, dried under vacuum and resuspended in an appropriate quantity of water.

\section{Microarray analysis}

In this study, Affymetrix mouse microarrays mouse expression (MOE) 430A were used. These arrays contain 22626 probe sets for approximately 14000 genes. The synthesis of fragmented cRNA from polysomal RNA and the hybridisation of the cRNA to the arrays were carried out by the Microarray facility at the University of Leicester and the MRC gene service at the University of Cambridge. To prepare the labelled targets for hybridisation to the array, polysomal RNA was reverse transcribed using an oligo-dT primer containing a $\mathrm{T} 7$ polymerase promoter. $\mathrm{T} 7$ polymerase was then used to generate double-stranded cDNA. The double-stranded cDNA was then transcribed in vitro to incorporate biotinylated CTP and UTP. The biotin-labelled cRNA was then fragmented and hybridised to the arrays. The arrays were washed, stained with a streptavidin-phycoerythrin conjugate and finally scanned. To determine changes in the gene expression, the signals from the baseline array $(0.5 \mathrm{mM}$ glucose $)$ were then compared with the control array (20 $\mathrm{mM}$ glucose). Analysis of the data was carried out using the MicroArray Suite 5 (MAS5, Affymetrix) using the following criteria: (1) probe sets with absent calls in both baseline $(0.5 \mathrm{mM}$ glucose $)$ and experimental $(20 \mathrm{mM}$ glucose) arrays were excluded; (2) probe sets with no change call between baseline and experimental arrays were excluded and (3) a threshold of 1.5- or 2-fold change in the levels of polysomal mRNAs between low and high glucose concentrations in the two individual experiments was included. Additional analysis was then carried out using Excel.

\section{Northern blotting}

RNA samples were heated at $65{ }^{\circ} \mathrm{C}$ for $10 \mathrm{~min}$ in RNA sample buffer (Sigma). RNA samples were cooled on ice and run on $1 \%$ agarose formaldehyde gels. RNA was transferred by capillary action onto Hybond-N membrane (Amersham Biosciences) and fixed. $\left[\alpha_{-}{ }^{32} \mathrm{P}\right]-\mathrm{dCTP}$ radio-labelled cDNA probes were generated using Prime-a-Gene labelling system (Promega). Unincorporated $\left[\alpha_{-}{ }^{32} \mathrm{P}\right]-\mathrm{dCTP}$ was removed by 
spinning through Probequant G50 columns (Amersham Biosciences). Membranes were pre-hybridised at $65{ }^{\circ} \mathrm{C}$ for $1 \mathrm{~h}$ in Church Gilbert solution $\left(0.5 \mathrm{M} \mathrm{NaHPO}_{4} \mathrm{pH} 7 \cdot 2\right.$, $1 \mathrm{mM}$ EDTA, 7\% SDS) supplemented with denatured salmon sperm DNA $(60 \mu \mathrm{g} / \mathrm{ml})$ prior to addition of the denatured radio-labelled probe and hybridisation overnight. The membranes were then washed twice for $15 \mathrm{~min}$ in $2 \times$ SSC, $0 \cdot 1 \%$ SDS at room temperature and once for $15 \mathrm{~min}$ in $0 \cdot 2 \times$ SSC, $0 \cdot 1 \%$ SDS at $60{ }^{\circ} \mathrm{C}$. The hybridised cDNA probes were visualised by autoradiography.

\section{SDS-PAGE and western blotting}

SDS-PAGE and western blotting were performed as described previously (Gomez et al. 2004). Anti-glutathione peroxidase 4 (GPx4), anti-c-Jun and anti-ATF4 (C-20) were purchased from AbCam Ltd, Cell Signalling Technologies, MA, USA, and Santa Cruz Biotechnology, Inc. Santa Cruz, CA, USA respectively. Anti-thioredoxin interacting protein antibody was purchased from Medical and Biological Laboratories Co. Ltd, Naka-Ku Nagoya, Japan.

\section{Results}

Analysis of pancreatic $\beta$-cell $m R N A$ translation profiles at both low and high glucose concentrations

Upon an increase in glucose concentration, there are rapid changes in the rate of protein expression through changes in the rate of translation from pre-existing transcripts (Guest et al. 1989, 1991). In order to identify proteins, whose expression is acutely regulated (within $1 \mathrm{~h}$ ) by glucose through an increase in their rate of protein synthesis, we analysed changes in the levels of mRNAs associated with polysomes (defined here as mRNAs bound to more than three ribosomes) in MIN6 cells, a pancreatic $\beta$-cell line that synthesises and secretes insulin in response to physiologically relevant glucose concentrations (Ishihara et al. 1993, Skelly et al. 1996), using affymetrix oligonucleotide microarrays.

MIN6 cells were incubated in KRB supplemented with $0.5 \mathrm{mM}$ glucose for $1 \mathrm{~h}$ and then further incubated in KRB supplemented with 0.5 or $20 \mathrm{mM}$ glucose for $1 \mathrm{~h}$, conditions that stimulated a $3 \cdot 27$-fold increase in insulin secretion (Fig. 1). Affymetrix microarray analysis was then used to determine differences in the quantity of polysomal mRNA between low and high glucose concentrations for transcripts from 14000 genes. This analysis revealed that the levels of 313 transcripts associated with polysomes changed by more than $1 \cdot 5$-fold (see Supplementary Data) between low and high glucose concentration in two separate experiments. The level of 37 of these transcripts changed by more than twofold between low and high glucose concentration in two separate experiments (Table 1). These glucose responsive genes, whose polysomal mRNA levels changed by more than 1.5- and 2-fold between low and high glucose concentrations in two separate



Figure 1 Glucose stimulated insulin secretion in MIN6 cells. MIN6 cells were pre-incubated in KRB containing $0.5 \mathrm{mM}$ glucose for $1 \mathrm{~h}$ followed by incubation in KRB containing 0.5 or $20 \mathrm{mM}$ glucose for a further hour. The amount of insulin secreted into the supernatants was determined by ELISA.

experiments, were functionally classified using the National Center for Biotechnology Information (NCBI) databases (www.ncbi.nlm.nih.gov) according to known cellular functions or sequence similarity to genes of known functions (Fig. 2). This classification revealed that the majority of polysomal mRNAs whose levels increased or decreased by 1.5-fold or more in response to increases in glucose concentration are involved in either metabolism or transcription (Fig. 2). This indicates that the acute regulation of metabolism and transcription are likely important for the $\beta$-cell to maintain the correct response to changes in glucose concentration. Further analysis revealed that the largest increases in the abundance of polysomal mRNAs encoded proteins associated with oxidative stress, indicating that the expression of these proteins is up-regulated in response to high glucose concentration (Table 2). These included an $8 \cdot 31$-fold glucose-stimulated increase in the amount of polysomal thioredoxin-2 (Trx2) mRNA, a mitochondrial thioredoxin that plays an important role in the thiol anti-oxidative pathway, a $3 \cdot 78$-fold increase in polysomal mRNAs encoding thioredoxin interacting protein (TrxIP) and a $2 \cdot 62$-fold increase in polysomal mRNAs encoding GPx4. The largest decreases in the abundance of polysomal mRNAs were of transcripts encoding proteins associated with the integrated stress response, indicating that the expression of these proteins is maintained/increased at low glucose concentration (Table 2). These included a 4.33-, 3.74- and 3.19-fold decrease in the amount of polysomal mRNA encoding the transcription factors c-Jun, C/EBP homologous protein (CHOP10) and activating transcription factor 4 (ATF4) respectively. Additionally, there was a $2 \cdot 75$-fold decrease in the amount of Tribbles homolog 3, a downstream effector of both CHOP10 and ATF4 (Ohoka et al. 2005, Ord \& Ord 2005). 
Table 1 List of polysomal mRNAs whose levels changed by more than twofold in response to an increase in glucose concentration in two independent experiments



Accession no.

Fold change $^{\mathrm{a}}$

\begin{tabular}{|c|c|}
\hline D86949 & $-2 \cdot 00$ \\
\hline AK014988 & $-2 \cdot 38$ \\
\hline NM_008426 & $-2 \cdot 47$ \\
\hline AK017926 & $-2 \cdot 56$ \\
\hline BQ174069 & $-2 \cdot 64$ \\
\hline BC012955 & $-2 \cdot 75$ \\
\hline NM_0135362 & $2 \cdot 32$ \\
\hline NM_019913 & $8 \cdot 31$ \\
\hline NM_023719 & $3 \cdot 78$ \\
\hline $\mathrm{AF} 274027$ & $2 \cdot 62$ \\
\hline C888802 & $2 \cdot 14$ \\
\hline NM_009665 & $2 \cdot 15$ \\
\hline ВС003494 & $2 \cdot 30$ \\
\hline AF192558 & $2 \cdot 00$ \\
\hline BC022110 & $-2 \cdot 07$ \\
\hline NM_007913 & $2 \cdot 75$ \\
\hline AV026617 & $2 \cdot 23$ \\
\hline NM_010347 & $2 \cdot 15$ \\
\hline NM_011793 & $2 \cdot 07$ \\
\hline AV025472 & $-2 \cdot 15$ \\
\hline BB333454 & $-2 \cdot 23$ \\
\hline NM_008321 & $-2 \cdot 23$ \\
\hline NM_009567 & $-2 \cdot 38$ \\
\hline NM_011760 & $-2 \cdot 49$ \\
\hline ВС023090 & $-2 \cdot 59$ \\
\hline ВС011183 & $-2 \cdot 70$ \\
\hline BB518874 & $-2 \cdot 07$ \\
\hline AV314773 & $-3 \cdot 19$ \\
\hline NM_007837 & $-3 \cdot 74$ \\
\hline NM_010193 & $-3 \cdot 98$ \\
\hline ВС002081 & $-4 \cdot 33$ \\
\hline L40934 & $2 \cdot 39$ \\
\hline ВС016408 & $2 \cdot 30$ \\
\hline NM_009112 & $2 \cdot 07$ \\
\hline BI692833 & $2 \cdot 15$ \\
\hline BM937429 & $-2 \cdot 07$ \\
\hline BC026760 & $2 \cdot 07$ \\
\hline
\end{tabular}

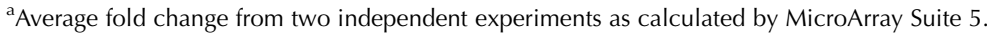

Polysome analysis of candidate anti-oxidative stress and integrated stress response $m R N A s$

Microarray analysis revealed that, at high glucose concentration, there was an increase in the association of a number of mRNAs with polysomes, encoding proteins implicated in the anti-oxidative pathway (Table 2). To confirm these changes, the sedimentation profiles of Trx 2 , TrxIP and GPx 4 mRNAs were determined in MIN6 cells incubated at either low or high glucose concentration by sucrose sedimentation gradient centrifugation followed by northern-blot analysis (Fig. 2a). Polysome profiles revealed that, upon an increase in glucose concentration from 0.5 to $20 \mathrm{mM}$, there is a large decrease in the $60 \mathrm{~S} / 80 \mathrm{~S}$ peak and a corresponding increase in the amount of polysomes (Fig. 3ai). This indicates that glucose stimulates the movement of ribosomes onto mRNAs and therefore suggests that glucose stimulates an increase in the global rate of initiation, results similar to those previously reported (Gomez et al. 2004). At low glucose concentration, northern-blot analysis of specific mRNAs across the gradient revealed that the majority of mRNA encoding GPx4, Trx 2 and TrxIP are associated with monosomes, disomes or trisomes and only a small proportion is associated with larger polysomes (Fig. 3aii). However, upon an increase in glucose concentration, these mRNAs were recruited onto heavier polysomes, indicative of 
a.

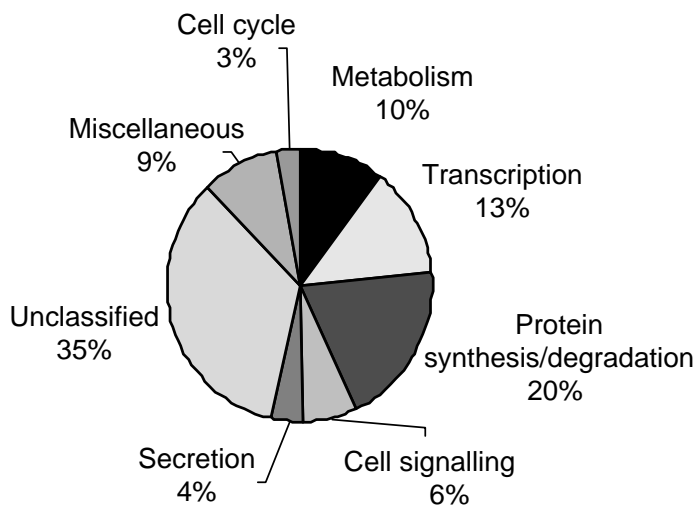

b.



Figure 2 Functional classification of polysomal mRNAs, whose levels changed by more than 2 -fold or more than $1 \cdot 5$-fold in response to an increase in glucose concentration. Polysomal mRNAs whose levels changed by more than $1 \cdot 5$-fold (a) or more than twofold (b) were functionally classified using NCBI databases (www.ncbi.nlm.nih.gov) according to known cellular functions or sequence similarity to genes of known functions. The proportional representation of each classification group was plotted on a pie chart.

Table 2 List of polysomal mRNAs associated with oxidative stress or the integrated stress response, whose levels changed by more than $1 \cdot 5$-fold in response to an increase in glucose concentration

\section{Accession no.}

\section{Gene name}

Oxidative stress

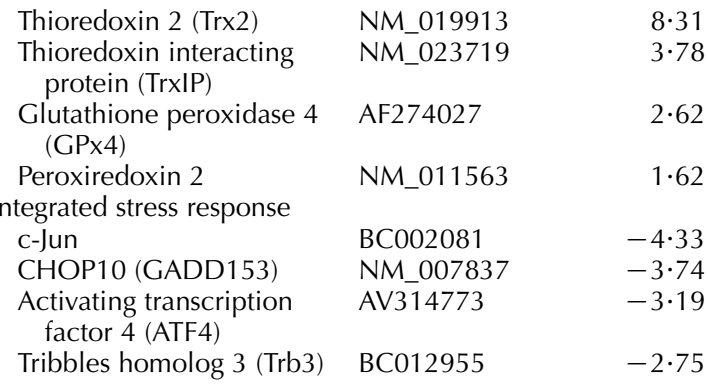

${ }^{a}$ Average fold change from two independent experiments as calculated by MicroArray Suite 5. an increase in the rate of their translation. These results demonstrate that ribosomes are recruited onto TrxIP, Trx2 and GPx4 mRNAs at high glucose and therefore confirm the results obtained by microarray analysis. In order to identify whether these increases in mRNA associated with polysomes were due to changes in the levels of total mRNA, northernblot analysis was carried out on total mRNA isolated from MIN6 cells incubated at either 0.5 or $20 \mathrm{mM}$ glucose for $1 \mathrm{~h}$ (Fig. 3b). Northern-blot analysis revealed that glucose stimulated a $2 \cdot 8$-fold increase in TrxIP mRNA, suggesting that short-term incubation at high glucose concentration led to an increase in either the stability and/or transcription of TrxIP mRNA (Fig. 3b). It has previously been reported that TrxIP is transcriptionally up-regulated in human and mouse islets following a 24-h incubation at high glucose (Shalev et al. 2002, Minn et al. 2005b). Therefore, at high glucose concentration, the expression of this protein is regulated by both a significant increase in its rate of transcription and by the recruitment of its mRNA into polysomes. In contrast, the level of GPx4 was unchanged and the level of Trx 2 mRNAs was only marginally increased in response to high glucose concentration (Fig. 3b). Therefore, an increase in the expression of these proteins is likely to be primarily mediated through an increase in the rate of protein synthesis.

In contrast, microarray analysis showed that the expression of a number of polysomal mRNAs associated with the integrated stress response was lower at high glucose concentration (see Table 2). To confirm these changes, the sedimentation profiles of CHOP10, ATF4 and c-Jun mRNAs were determined in MIN6 cells incubated at either low or high glucose by sucrose sedimentation gradient centrifugation followed by northern-blot analysis (Fig. 3a). Paradoxically, at low glucose concentration, CHOP10, ATF4 and c-Jun mRNAs were all found to co-sediment with heavy polysomes, indicating that these mRNAs are likely to be actively engaged in protein synthesis at low glucose (Fig. 3aii). Upon an increase in glucose concentration, there was a significant shift of CHOP10 and ATF4 mRNA off polysomes and into monosomes, indicative of a decrease in their expression (Fig. 3aii). Therefore, at low glucose concentration, the expressions of CHOP10 and ATF4 are likely up-regulated through an increase in their rate of translation. In contrast, c-Jun mRNA remained associated with polysomes but the level of c-Jun mRNA decreased dramatically. To ascertain whether the expression of these proteins was also regulated through changes in mRNA abundance, total RNA was isolated from MIN6 cells that were incubated at low or high glucose concentration and the mRNA levels of ATF4, CHOP10 and c-Jun were determined by northern-blot analysis. Northern blots showed that CHOP10 mRNA levels were $1 \cdot 7$-fold higher at low glucose compared with high glucose, indicating that glucose acutely regulates the expression of this protein by both transcriptional and translational mechanisms. ATF4 mRNA levels were only marginally increased at low glucose. Therefore, the increase in the expression of ATF4 at low 
a.

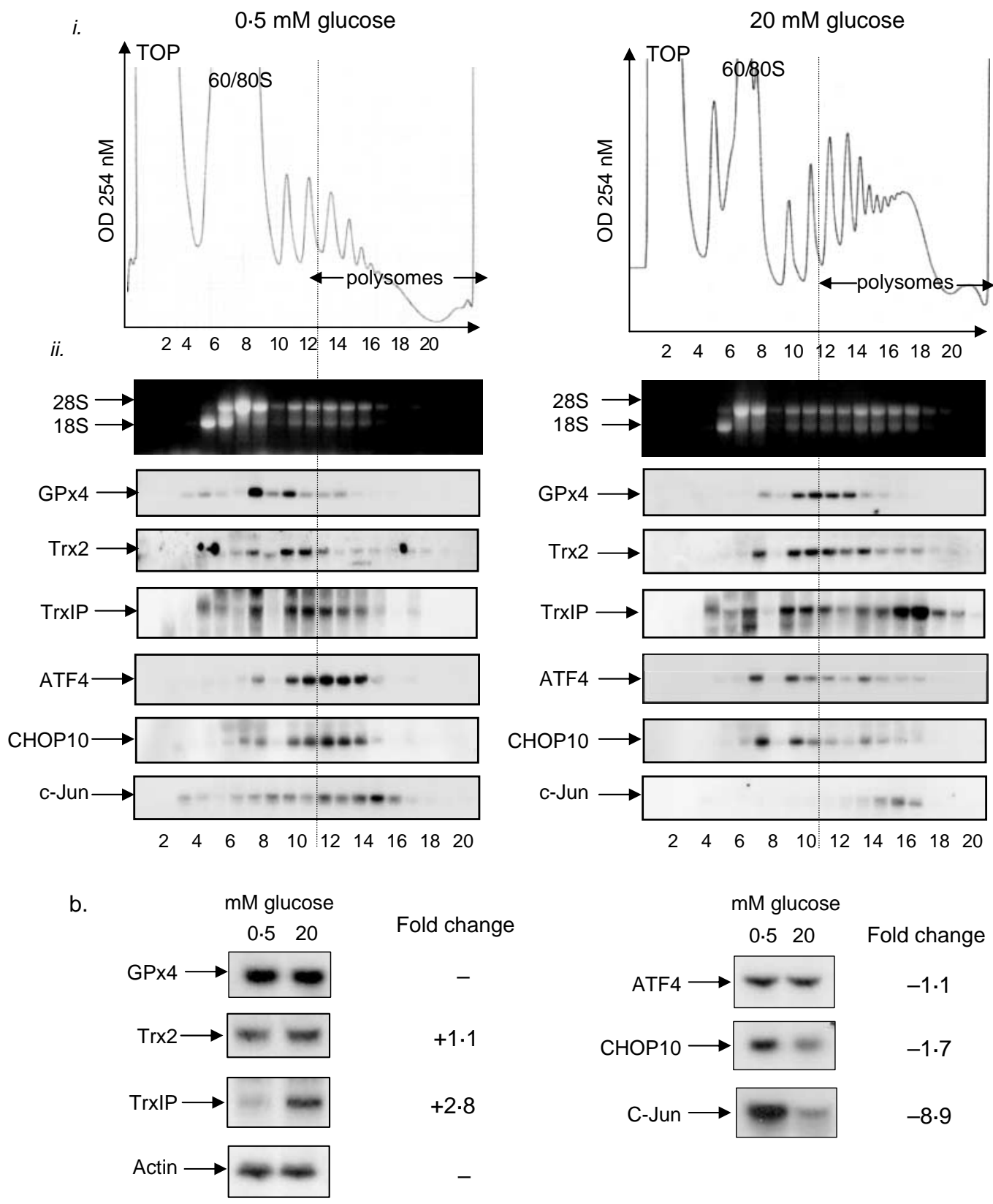

Figure 3 Polysome analysis of mRNAs associated with oxidative stress. MIN6 cells were pre-incubated in KRB containing $0.5 \mathrm{mM}$ glucose for $1 \mathrm{~h}$ followed by incubation in KRB containing 0.5 or $20 \mathrm{mM}$ glucose for a further hour. (a) Cells were lysed and polysome analysis was carried out using $20-50 \%$ sucrose gradients. The gradients were fractionated from top (fraction 1) to bottom (fraction 20). (a. i) Absorbance of the gradients was measured continuously at $254 \mathrm{~nm}$ to give polysome profiles. (a. ii) RNA was isolated from each fraction and run on $1 \%$ agarose formaldehyde gel. RNA was transferred onto nylon membrane and probed for the mRNAs indicated. The results presented are representative of three separate experiments. (b) Cells were lysed and total RNA isolated. The RNA was then run on $1 \%$ agarose formaldehyde gel, transferred onto nylon membrane and probed for specific mRNAs as shown. The fold changes observed in the northern blot between low and high glucose concentrations were quantified with ImageJ. The results presented in this figure are representative of three separate experiments. 
glucose is likely primarily mediated through an increase in the rate of protein synthesis. In contrast, the level of c-Jun mRNA decreased dramatically between low and high glucose (8.9-fold decrease) and therefore the expression of this protein is likely primarily regulated by glucose through changes in mRNA abundance.

Glucose regulates the protein levels of anti-oxidative stress and integrated stress response proteins

To ascertain whether the changes in the association of mRNA with polysomes identified by microarray analysis correlated with changes in protein expression, MIN6 cells were incubated at 0.5 or $20 \mathrm{mM}$ glucose for up to $4 \mathrm{~h}$ and the expression levels of a number of candidate proteins determined by western blotting (Fig. 4). The protein expression levels of ATF4 were much higher at low glucose concentration than at high glucose concentration throughout the period of the experiment. The level of c-Jun protein significantly decreased after $4 \mathrm{~h}$ incubation at high glucose concentration, whereas the levels of c-Jun protein were maintained for up to $4 \mathrm{~h}$ at low glucose concentration. These results provide evidence that the rate of c-Jun and ATF4 protein synthesis is higher at low glucose concentration than at high glucose concentration. These results are consistent with our microarray data demonstrating that ATF4 and c-Jun mRNAs are recruited onto polysomes at low glucose concentration. In contrast, TrxIP protein levels were rapidly decreased at low glucose (within 1-2 h) but maintained at high glucose concentration. These results are also consistent with our microarray results demonstrating that TRxIP is recruited onto polysomes at high glucose concentration. The protein levels of GPx4 also increased after $1-2 \mathrm{~h}$ at high glucose concentration, again consistent with our microarray data.

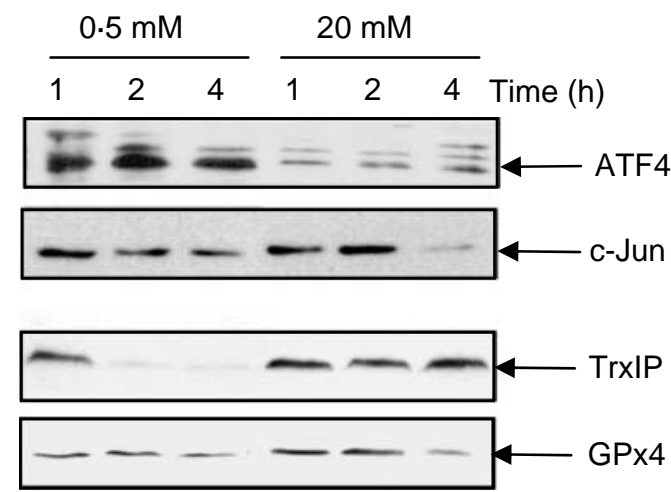

Figure 4 Glucose regulated protein expression. MIN6 cells were incubated in KRB at either 0.5 or $20 \mathrm{mM}$ glucose for the times indicated. Samples of cell lysates were run on a SDS-polyacrylamide gel followed by western blotting using antisera against ATF4, c-Jun, TrxIP and GPx4.

\section{Supplementary data}

A list of polysomal mRNAs whose levels changed by more than 1.5-fold in response to an increase in glucose concentration is presented (http://joe.endocrinology-journals.org/cgi/ content/full/192/1/DC1). Polysomal mRNAs whose levels were shown to increase or decrease by more than 1.5 fold in response to $1 \mathrm{~h}$ glucose stimulation in two separate experiments are listed. Analysis was carried out using MAS5.

\section{Discussion}

Translational profiling of the pancreatic $\beta$-cell line MIN6 revealed the identity of a large number of mRNAs that are rapidly redistributed on or off polysomes in response to changes in glucose concentration, indicative of changes in their rates of synthesis. Functional analysis of these glucoseregulated genes showed that 34 and $46 \%$ of mRNAs, whose abundance on polysomes changed by more than 1.5- and 2-fold respectively were associated with gene expression (Fig. 2).

In response to high glucose concentration, the general rate of protein synthesis increases, primarily mediated through an increase in the rate of translation initiation (Gomez et al. 2004). However, paradoxically, the association of a number of transcripts with polysomes increased in response to a decrease in glucose concentration, indicating that translation from these transcripts is up-regulated at low glucose concentration. These included transcripts that encode b-zip transcription factors, ATF4, CHOP10 and c-Jun, whose expression has previously been shown to be up-regulated in response to an increase in the phosphorylation of eIF2 $\alpha$, as part of the integrated stress response (Harding et al. 2003). Indeed, we have previously demonstrated that eIF $2 \alpha$ is phosphorylated in response to low glucose concentration in MIN6 cells (Gomez et al. 2004). The amount of total ATF4 mRNA is slightly higher at low glucose compared with high glucose concentration, suggesting that glucose deprivation also stimulates the transcription of ATF4 or increases the stability of ATF4 mRNA. However, the redistribution of ATF4 mRNA on polysomes between high and low glucose indicate that its expression is primarily regulated at the post-transcriptional level through an increase in the rate of protein synthesis. Indeed, the mechanism by which ATF4 is up-regulated when general translation is repressed through the phosphorylation of eIF2 $\alpha$ is known (Lu et al. 2004, Vattem \& Wek 2004). Essentially, ATF4 expression is regulated by short open reading frames (uORFs) within its $5^{\prime}$ untranslated region $\left(5^{\prime} \mathrm{UTR}\right)$ by a mechanism analogous to that which regulates general control non depressible 4 (GCN4) expression in yeast (Lu et al. 2004, Vattem \& Wek 2004). Briefly, GCN4 mRNA contains four upstream open reading frames (uORFs) in its $5^{\prime} \mathrm{UTR}$. Under non-stressed conditions, when eIF $2 \alpha$ is unphosphorylated and the availability of the translational ternary complex is high, the ribosome initiates at the $5^{\prime}$ proximal uORF. Upon 
termination of $\mathrm{uORF} 1$, the ribosome remains associated with the mRNA and, due to the availability of ternary complex, is able to reinitiate at inhibitory ORF 2, 3 and 4 which overlaps the coding region of GCN4, thereby bypassing the authentic initiation codon. In stressed conditions, when $\operatorname{eIF} 2 \alpha$ is phosphorylated and the availability of the translational ternary complex is low, there is a delay in reinitiation that allows the ribosome to bypass the inhibitory uORFs and initiate at the authentic initiation codon, resulting in the expression of GCN4 (Hinnebusch 1994).

At low glucose concentration, the mRNA encoding CHOP10 (GADD153), a downstream target of ATF4 (Harding et al. 2000), and c-jun were also found to be associated with polysomes, indicating that the expression of these proteins is up-regulated at low glucose concentration. Northern-blot analysis of total RNA indicates that there are acute changes in the abundance of these mRNA in response to glucose, indicating that both changes in the mRNA stability/rates of transcription are clearly important in regulating their expression. Microarray analysis of MIN6 cells incubated at low or high glucose concentration for $24 \mathrm{~h}$ showed that CHOP expression was increased at low glucose concentration (Webb et al. 2000, 2001). The mechanism by which the synthesis of CHOP10 and c-Jun is maintained at low glucose concentration is unknown. However, it is likely that the rapid up-regulation of these integrated stress response proteins are necessary for the $\beta$-cell to respond to stress induced by glucose deprivation.

At high glucose concentration, a number of mRNAs that play an important role in the regulation of oxidative stress, including key members of the thioredoxin and glutathione anti-oxidative systems moved onto heavy polysomes, indicative of an increase in their rates of translation and therefore protein expression. These included the mitochondrial thioredoxin Trx2, GPx4 and peroxiredoxin-2 (Table 2). Changes in abundance of mRNAs on polysomes were independent of changes in transcript levels. Therefore, any changes in the expression of these proteins in response to an acute increase in glucose concentration are mediated at the post-transcriptional level via an increase in the rate of translation from pre-existing mRNA.

The $\beta$-cell is particularly vulnerable to oxidative stress, probably due to its low anti-oxidative enzyme activity, which makes it difficult to inactivate reactive oxygen species (Grankvist et al. 1981, Lenzen et al. 1996, Tiedge et al. 1997). This weakness of the $\beta$-cell to combat oxidative stress is thought to be an important factor in the development of diabetes, as it can lead to $\beta$-cell dysfunction and apoptosis, a major form of $\beta$-cell loss in both type I and type II diabetes. As it has previously been demonstrated that the over-expression of thioredoxin-1 protects mice from streptozotocin-induced diabetes (Hotta et al. 1998) and the over-expression of glutathione peroxidase protects $\beta$-cells from oxidative stress (Robertson et al. 2005), it is likely that the up-regulation of $\operatorname{Tr} 2$; GPx4 and peroxiredoxin-2 are important in protecting against hyperglycaemia-induced oxidative stress. Paradoxically, microarray analysis indicated that, in response to high glucose concentration, there was also an increase in the expression of TrxIP, a protein that binds to the active site of thioredoxin-1 and inhibits its activity. This increase in expression is primarily mediated through an increase in transcript number, as glucose stimulated a large increase in TrxIP mRNA abundance (Fig. 3). Indeed, it has previously been demonstrated, in both islets and pancreatic $\beta$-cells, that glucose stimulates the transcription of TrxIP (Minn et al. 2005a). Up-regulating TrxIP results in the inhibition of thioredoxin's reactive oxygen species scavenging function, resulting in increased cellular oxidative stress. This may be an important mechanism by which hyperglycaemia induces oxidative stress and subsequent pancreatic $\beta$-cells apoptosis (Schulze et al. 2004). Indeed, over-expression of TrxIP induces apoptosis in islets (Minn et al. 2005a). Interestingly, glutathione peroxidase and thioredoxin have also been implicated in regulating glucose-stimulated insulin secretion mediated by increases in NADPH (Ivarsson et al. 2005).

This study does not provide a comprehensive list of proteins, whose expression is acutely up- or down-regulated in response to glucose. Indeed, it is important to note that the expression of proteins, whose mRNA abundance does not appear to change on polysomes could still be acutely up- or down-regulated by glucose. However, changes in the abundance of mRNAs on polysomes in response to glucose detected in this report likely parallels the changes in the expression levels of the proteins they encode. Indeed, this study provides evidence that hyperglycaemia up-regulates a number of proteins responsible for regulating the redox status of the $\beta$-cell. Deregulation of the redox state of the cell by glucose is likely to play an important role in the development of $\beta$-cell dysfunction and type II diabetes. Additionally, this study revealed that the integrated stress response is activated at low glucose concentration, which is an important mechanism for alleviating ER stress and therefore increasing cell survival (Harding et al. 2003).

In conclusion, this study has identified a number of proteins that are acutely regulated by glucose. Further analysis and characterisation of the function of these proteins in response to changing glucose concentration is likely to provide a better understanding of the processes important in the development of diabetes.

\section{Acknowledgements}

I C G was supported by a Biotechnology and Biological Sciences Research Council case studentship. E G was supported the Wellcome Trust. C M is supported by an MRC studentship. The authors declare that there is no conflict of interest that would prejudice the impartiality of this scientific work. 


\section{References}

Campbell IL, Hellquist LN \& Taylor KW 1982 Insulin biosynthesis and its regulation. Clinical Science 62 449-455.

Garcia-Barrado MJ, Ravier MA, Rolland JF, Gilon P, Nenquin M \& Henquin JC 2001 Inhibition of protein synthesis sequentially impairs distinct steps of stimulus-secretion coupling in pancreatic beta cells. Endocrinology 142 299-307.

Gomez E, Powell ML, Greenman IC \& Herbert TP 2004 Glucose-stimulated protein synthesis in pancreatic $\beta$-cells parallels an increase in the availability of the translational ternary complex (eIF2-GTP.Met-tRNAi) and the dephosphorylation of eIF2 $\alpha$. Journal of Biological Chemistry 279 5393753946.

Grankvist K, Marklund SL \& Taljedal IB 1981 CuZn-superoxide dismutase, $\mathrm{Mn}$-superoxide dismutase, catalase and glutathione peroxidase in pancreatic islets and other tissues in the mouse. Biochemical Journal 199 393-398.

Guest PC, Rhodes CJ \& Hutton JC 1989 Regulation of the biosynthesis of insulin-secretory-granule proteins. Co-ordinate translational control is exerted on some, but not all, granule matrix constituents. Biochemical Journal 257 431-437.

Guest PC, Bailyes EM, Rutherford NG \& Hutton JC 1991 Insulin secretory granule biogenesis. Co-ordinate regulation of the biosynthesis of the majority of constituent proteins. Biochemical Journal 274 73-78.

Harding HP, Novoa I, Zhang Y, Zeng H, Wek R, Schapira M \& Ron D 2000 Regulated translation initiation controls stress-induced gene expression in mammalian cells. Molecular Cell 6 1099-1108.

Harding HP, Zhang Y, Zeng H, Novoa I, Lu PD, Calfon M, Sadri N, Yun C, Popko B, Paules R et al. 2003 An integrated stress response regulates amino acid metabolism and resistance to oxidative stress. Molecular Cell 11 619-633.

Hinnebusch AG 1994 Translational control of GCN4: an in vivo barometer of initiation-factor activity. Trends in Biochemical Sciences 19 409-414.

Hotta M, Tashiro F, Ikegami H, Niwa H, Ogihara T, Yodoi J \& Miyazaki J 1998 Pancreatic beta cell-specific expression of thioredoxin, an antioxidative and antiapoptotic protein, prevents autoimmune and streptozotocin-induced diabetes. Journal of Experimental Medicine 188 1445-1451.

Ishihara H, Asano T, Tsukuda K, Katagiri H, Inukai K, Anai M, Kikuchi M, Yazaki Y, Miyazaki JI \& Oka Y 1993 Pancreatic beta cell line MIN6 exhibits characteristics of glucose metabolism and glucose-stimulated insulin secretion similar to those of normal islets. Diabetologia 36 1139-1145.

Itoh N \& Okamoto H 1980 Translational control of proinsulin synthesis by glucose. Nature 283 100-102.

Itoh N, Sei T, Nose K \& Okamoto H 1978 Glucose stimulation of the proinsulin synthesis in isolated pancreatic islets without increasing amount of proinsulin mRNA. FEBS Letters 93 343-347.

Ivarsson R, Quintens R, Dejonghe S, Tsukamoto K, in't Veld P, Renstrom E \& Schuit FC 2005 Redox control of exocytosis: regulatory role of NADPH, thioredoxin, and glutaredoxin. Diabetes 54 2132-2142.

Johannes G, Carter MS, Eisen MB, Brown PO \& Sarnow P 1999 Identification of eukaryotic mRNAs that are translated at reduced cap binding complex eIF4F concentrations using a cDNA microarray. PNAS 96 13118-13123.

Lenzen S, Drinkgern J \& Tiedge M 1996 Low antioxidant enzyme gene expression in pancreatic islets compared with various other mouse tissues. Free Radical Biology and Medicine 20 463-466.

Lu PD, Harding HP \& Ron D 2004 Translation reinitiation at alternative open reading frames regulates gene expression in an integrated stress response. Journal of Cell Biology 167 27-33.
Mikulits W, Pradet-Balade B, Habermann B, Beug H, Garcia-Sanz JA \& Mullner EW 2000 Isolation of translationally controlled mRNAs by differential screening. FASEB Journal 14 1641-1652.

Minn AH, Hafele C \& Shalev A 2005a Thioredoxin-interacting protein is stimulated by glucose through a carbohydrate response element and induces beta-cell apoptosis. Endocrinology 146 2397-2405.

Minn AH, Pise-Masison CA, Radonovich M, Brady JN, Wang P, Kendziorski C \& Shalev A $2005 b$ Gene expression profiling in INS-1 cells overexpressing thioredoxin-interacting protein. Biochemical and Biophysical Research Communications 336 770-778.

Ohoka N, Yoshii S, Hattori T, Onozaki K \& Hayashi H 2005 TRB3, a novel ER stress-inducible gene, is induced via ATF4-CHOP pathway and is involved in cell death. EMBO Journal 24 1243-1255.

Ohsugi M, Cras-Meneur C, Zhou Y, Warren W, Bernal-Mizrachi E \& Permutt MA 2004 Glucose and insulin treatment of insulinoma cells results in transcriptional regulation of a common set of genes. Diabetes 53 1496-1508.

Ord D \& Ord T 2005 Characterization of human NIPK (TRB3, SKIP3) gene activation in stressful conditions. Biochemical and Biophysical Research Communications 330 210-218.

Robertson RP, Tanaka Y, Takahashi H, Tran PO \& Harmon JS 2005 Prevention of oxidative stress by adenoviral overexpression of glutathionerelated enzymes in pancreatic islets. Annals of the New York Academy of Sciences 1043 513-520.

Schulze PC, Yoshioka J, Takahashi T, He Z, King GL \& Lee RT 2004 Hyperglycemia promotes oxidative stress through inhibition of thioredoxin function by thioredoxin-interacting protein. Journal of Biological Chemistry 279 30369-30374.

Shalev A, Pise-Masison CA, Radonovich M, Hoffmann SC, Hirshberg B, Brady JN \& Harlan DM 2002 Oligonucleotide microarray analysis of intact human pancreatic islets: identification of glucose-responsive genes and a highly regulated TGFbeta signaling pathway. Endocrinology 143 3695-3698.

Skelly RH, Schuppin GT, Ishihara H, Oka Y \& Rhodes CJ 1996 Glucoseregulated translational control of proinsulin biosynthesis with that of the proinsulin endopeptidases PC2 and PC3 in the insulin-producing MIN6 cell line. Diabetes 45 37-43.

Tiedge M, Lortz S, Drinkgern J \& Lenzen S 1997 Relation between antioxidant enzyme gene expression and antioxidative defense status of insulin-producing cells. Diabetes 46 1733-1742.

Vattem KM \& Wek RC 2004 Reinitiation involving upstream ORFs regulates ATF4 mRNA translation in mammalian cells. PNAS 101 $11269-11274$.

Webb GC, Akbar MS, Zhao C \& Steiner DF 2000 Expression profiling of pancreatic beta cells: glucose regulation of secretory and metabolic pathway genes. PNAS 97 5773-5778.

Webb GC, Akbar MS, Zhao C \& Steiner DF 2001 Expression profiling of pancreatic beta cells: glucose regulation of secretory and metabolic pathway genes. Diabetes 50(Suppl 1) S135-S136.

Received in final form 4 October 2006

Accepted 5 October 2006

Made available online as an Accepted Preprint 18 October 2006 